\title{
Kajian Alokasi Kebutuhan Ruang di Provinsi Sumatera Utara
}

\author{
Dessy Eresina Pinem ${ }^{1}$ \\ Institut Teknologi Medan \\ Medan, Indonesia
}

Bambang Benediktus Sianipar2

PT. Gamma Engineering

Medan, Sumatera Utara, Indonesia

\section{Purnama ${ }^{3}$}

PT Cita Kreasi Latena

Medan, Sumatera Utara, Indonesia

Artikel Masuk : 9 November 2015

Artikel Diterima : 11 Desember 2015

Tersedia Online : 30 Desember 2015

\begin{abstract}
Abstrak: Sejalan dengan perkembangan pembangunan, maka desakan terhadap perubahan ruang-ruang alami untuk lahan terbangun seperti perumahan, perkantoran, pertokoan, jalan dan lapangan parkir maupun bentuk lahan lain menjadi semakin tinggi. Kondisi ini berdampak pada menurunnya jumlah ruang yang dapat dipergunakan bagi pertanian, tanaman sayuran dan holtikultura. Padahal, hasil pertanian diperlukan untuk penyediaan bahan pangan penduduk. Kasus khusus di Provinsi Sumatera Utara, perkembangan sektor unggulan yaitu perkebunan sawit dan karet juga terus berkembang sehingga membutuhkan ruang. Oleh sebab itu, terjadi 'kompetisi' pada berbagai aktivitas yang membutuhkan ruang di Provinsi Sumatera Utara. Tujuan penelitian adalah untuk menganalisis kebutuhan ruang di Provinsi Sumatera Utara dibandingkan dengan ketersediaan dan kesesuaian lahan yang ada. Pada studi ini, kebutuhan ruang dihitung melalui jumlah kebutuhan pangan seluruh penduduk Provinsi Sumatera Utara yang disesuaikan dengan Sasaran Konsumsi Pangan Utama Provinsi Sumatera Utara tahun 2025, jumlah luas lahan yang dibutuhkan untuk permukiman yang disesuaikan dengan jumlah penduduk Provinsi Sumatera Utara tahun 2025, jumlah luas lahan yang dibutuhkan untuk perkembangan produksi perkebunan sawit yang merupakan sektor unggulan Provinsi Sumatera Utara, jumlah luas lahan yang dibutuhkan untuk perkembangan produksi pertanian dan holtikultura untuk memenuhi kebutuhan penduduk Provinsi Sumatera Utara sampai tahun 2025. Peramalan jumlah produksi pertanian menggunakan regresi linier sederhana. Kesesuaian dan kemampuan lahan diukur melalui Satuan Kemampuan Lahan (SKL) yang menunjukkan lahan yang sesuai untuk kawasan lindung, kawasan permukiman,
\end{abstract}

\footnotetext{
${ }^{1}$ Korespondensi Penulis: Institut Teknologi Medan, Medan, Indonesia

Email: eresina22@yahoo.com

${ }^{2}$ Korespondensi Penulis: Ahli GIS, Medan, Indonesia

Email: bambangsianipar@gmail.com

${ }^{3}$ Korespondensi Penulis: Konsultan Tata Ruang, Medan, Indonesia

Email: purnamatrand@gmail.com
} 
hutan, mangrove, penggembalaan ternak, pertanian semusim, tanaman tahunan, dan lainnya. Hasil analisis menunjukkan bahwa terjadi kekurangan lahan untuk pertanian pada tahun 2025 sebesar 596.485,44 ha akibat konversi lahan pertanian untuk kawasan permukiman, perkebunan, dan lainnya. Berdasarkan kesesuaian lahan untuk pertanian semusim lahan basah dan kering, pada tahun 2025 masih terdapat lahan sebesar 1.410.363,07 ha yang dapat ditanami sayuran. Di tahun 2025 juga akan terjadi kekurangan lahan untuk perumahan sebesar $185.638,54$ ha. Temuan lainnya adalah apabila produktivitas tetap, maka pada tahun 2025, produksi padi Provinsi Sumatera Utara dapat memenuhi kebutuhan beras untuk ketahanan pangan asalkan lahan pertanian sampai tahun 2025 masih dialokasikan.

Kata Kunci: kebutuhan ruang, satuan kemampuan lahan, regresi linier sederhana

\begin{abstract}
Following development pressures, many natural land uses have increasingly changed to built-up areas for various functions such as housing, offices, shops, roads and parking space. This condition implies on the decrease of space availability for agriculture, vegetableplanting, and horticulture. In fact, the agriculture products are required for the local food security. In thecase of North Sumatera, the development of leading sectors in palm and rubber industries requires more spaces, creating spatial rivalry against other sectors. The research aimed to analyze the spatial development needs in North Sumatera Province in accordance with the land availability and suitability. In this study, the spatial needs were calculated by considering actual and targeted food consumption levels in 2025, the amount of land required for total population settlement in 2015, for palm plantation, and for agriculture and horticulture farmingin 2025. The forecasting of agriculture production was conducted by using simple linear regression. The land suitability and capability were measured through Satuan Kemampuan Lahan (Land Ability Unit) to show the land suitability to protected areas, residential areas, forests, mangroves, cattle grazing, annual agriculture, perennial plants, and others. The results showed that there was a shortage of agriculture land in 2025 about 596,485.44 hectares due to land conversion from agriculture to settlement, plantation, and others. Based on the land suitability of seasonal wet and drylands, there were 1,410,363.07 hectares of land appropriate for vegetable plantation in 2025 and shortage of land availability for housing about 185,638.54 hectares. The other finding was of the fulfilment of targeted rice production in 2025 as long as the allocated land for agriculture farming remains secured even though its productivity unchanged.
\end{abstract}

Keywords: space requirements, the unit of land capability, simple linear regression

\title{
Pendahuluan
}

Sejalan dengan perkembangan pembangunan, maka desakan terhadap perubahan ruang-ruang alami untuk lahan terbangun seperti perumahan, perkantoran, pertokoan, jalan dan lapangan parkir maupun bentuk lahan lain menjadi semakin tinggi. Kondisi ini berdampak pada menurunnya jumlah ruang yang dapat dipergunakan bagi pertanian, tanaman sayuran dan holtikultura. Di sisi lain, hasil pertanian terus diperlukan terutama untuk penyediaan bahan pangan bagi penduduk. Kasus khusus di Provinsi Sumatera Utara, perkembangan sektor unggulan yaitu perkebunan sawit dan karet juga terus berkembang sehingga membutuhkan ruang. Kondisi ini menimbulkan 'kompetisi' pada berbagai aktivitas yang membutuhkan ruang di Provinsi Sumatera Utara. Oleh sebab itu, perlu dilakukan suatu analisis mengenai kebutuhan ruang di Provinsi Sumatera Utara. Analisis ini didasarkan pada proyeksi kebutuhan ruang untuk memenuhi perkembangan jumlah penduduk hingga tahun 2025, jumlah perkembangan sektor unggulan (perkebunan), jumlah kebutuhan ruang untuk pertanian. Semua kebutuhan ruang terus akan dibandingkan dengan kesediaan dan kesesuaian lahan yang ada. 
'Kompetisi' ruang untuk permukiman dan pertanian mengingatkan kita pada teori Malthus. Dalam tulisannya berjudul Essay on Population tahun 1978, dimana disebutkan bahwa pertumbuhan manusia akan jauh lebih cepat dibandingkan dengan produksi bahan makanan. Pertumbuhan penduduk meningkat secara geometris (deret ukur) dan produksi bahan pangan akan tumbuh secara aritmatik (deret hitung) sehingga pada akhirnya, menurut Malthus, akan terjadi perbedaan yang besar antara jumlah penduduk dan jumlah produksi bahan pangan. Oleh sebab itu, untuk menjaga agar bahan pangan tetap ada, diperlukan perhatian khusus dan perhitungan berapa besar lahan harus disiapkan untuk produksi bahan pangan untuk memenuhi kebutuhan penduduk.

Penelitian ini didasarkan pada pemahaman bahwa diperlukannya keseimbangan antara konsep kebutuhan (concept of needs) dan konsep keterbatasan (concept of limitation) pada pembangunan kota atau wilayah yang berkelanjutan (Nurhayati, 2009). Konsep pemenuhan kebutuhan difokuskan untuk meningkatkan kualitas hidup manusia sementara konsep keterbatasan adalah ketersediaan dan kapasitas yang dimiliki lingkungan untuk memenuhi kebutuhan dan keterbatasan yang ada saat ini. Upaya keseimbangan itu dapat dilakukan dari dua arah yaitu dengan mengendalikan kebutuhan dengan cara mengubah perilaku konsumsi dan sebaliknya meningkatkan kemampuan untuk meminimalkan keterbatasan melalui pengembangan teknologi, finansial dan institusi. Sebagai conto daya dukung lahan dipengaruhi oleh faktor luas panen dan produktivitas pertanian (Moniaga, 2011).

Konsep keterbatasan diwujudkan dengan mengukur daya dukung (carrying capacity) lingkungan. Menurut Greymore (2003 dalam Nurhayati, 2009), daya dukung lingkungan adalah jumlah maksimum manusia yang dapat didukung oleh bumi dengan sumber daya alam yang tersedia. Jumlah maksimum tersebut adalah jumlah yang tidak menyebabkan kerusakan pada lingkungan dan kehidupan di bumi dapat berlangsung secara sustainable. Greymore juga menyatakan bahwa daya dukung lingkungan sangat ditentukan oleh pola konsumsi, jumlah limbah yang dihasilkan, dampak bagi lingkungan, kualitas hidup dan tingkat teknologi. Batas daya dukung ekosistem tergantung pada tiga faktor yaitu:

a. Jumlah sumberdaya alam yang tersedia dalam ekosistem tersebut

b. Jumlah atau ukuran populasi atau komunitas

c. Jumlah sumberdaya alam yang dikonsumsi oleh setiap individu dalam komunitas/ populasi tersebut.

Pada studi ini, konsep kebutuhan dihitung melalui:

1. Jumlah kebutuhan pangan seluruh penduduk Provinsi Sumatera Utara yang disesuaikan dengan Sasaran Komsumsi Pangan Utama Provinsi Sumatera Utara tahun 2025.

2. Jumlah luas lahan yang dibutuhkan untuk permukiman yang disesuaikan dengan jumlah penduduk Provinsi Sumatera Utara tahun 2025.

3. Jumlah luas lahan yang dibutuhkan untuk perkembangan produksi perkebunan sawit yang merupakan sektor unggulan Provinsi Sumatera Utara.

4. Jumlah luas lahan yang dibutuhkan untuk perkembangan produksi pertanian dan holtikultura untuk memenuhi kebutuhan penduduk Provinsi Sumatera Utara sampai tahun 2025.

Di sisi lain, konsep keterbatasan diukur melalui:

1. Penggambaran Satuan Kemampuan Lahan (SKL) yaitu SKL Morfologi, SKL kemudahan dikerjakan, SKL kestabilan lereng, SKL ketersediaan air, SKL drainase, SKL erosi, SKL pembuangan limbah, dan SKL bencana alam yang akan menunjukkan lahan yang sesuai untuk kawasan lindung, kawasan permukiman, hutan, manggrove, penggembalaan ternak, pertanian semusim, tanaman tahunan, dan lain-lain. 
2. Penggambaran penggunaan lahan eksisting, misalnya lahan yang sesuai untuk pertanian telah digunakan untuk perkebunan sehingga perkembangan pertanian akan terganggu.

\section{Metodologi Penelitian}

Ada beberapa pengolahan data yang digunakan pada penelitian ini:

1. Jumlah kebutuhan pangan penduduk Provinsi Sumatera Utara ditentukan berdasarkan besar Konsumsi Pangan Utama Provinsi Sumatera Utara yang ditentukan pada Grand Design Ketahanan Pangan Provinsi Sumatera Utara tahun 2012-2025.

2. Jumlah luas lahan yang dibutuhkan untuk permukiman diambil dari besar alokasi permukiman di tiap kab/kota di Propinsi Sumatera Utara yang tercantum pada RTRW Propinsi Sumatera Utara 2013-2033.

3. Jumlah luas lahan yang diperlukan untuk perkebunan diambil dari perkiraan perkembangan luas lahan perkebunan yang tercantum pada RTRW Propinsi Sumatera Utara 2013-2033.

4. Jumlah luas lahan yang diperlukan untuk perkembangan pertanian dan tanaman holtikultura dihitung menggunakan peramalan produksi pertanian dan holtikultura dengan metoda regresi linier sederhana. Dengan menggunakan metoda ini, maka trend jumlah produksi akan mengikuti trend 5-10 tahun sebelumnya. Jumlah produksi pertanian dan holtikultura sebenarnya dipengaruhi oleh faktor teknologi, intensifikasi pertanian, kebijakan bidang pertanian, dll. Namun dalam penelitian ini, perhitungan jumlah produksi didasarkan pada kelanjutan trend produktivitas 5-10 tahun sebelumnya. Faktor teknologi, intensifikasi pertanian, kebijakan pertanian lainnya, tidak diperhitungkan.

5. Penggambaran SKL mengikuti metoda dari Permen PU no 20/PRT/2007 tentang Pedoman Teknik Analisis Aspek Fisik dan Lingkungan, Ekonomi, serta Sosial Budaya dalam Penyusunan Rencana Tata Ruang.

Data untuk pembuatan peta SKL menggunakan foto udara (citra) Provinsi Sumatera Utara yang diambil tahun 2013.

\section{Metode Regresi dalam Peramalan}

Penggunaan metode ini didasarkan kepada variabel yang ada dan yang akan mempengaruhi hasil peramalan. Hal- hal yang perlu diketahu sebelum melakukan peramalan dengan metode regresi adalah mengetahui terlebih dahulu mengetahui kondisikondisi seperti:

a. Adanya informasi masa lalu

b. Informasi yang ada dapat dibuatkan dalam bentuk data (dikuantifikasikan)

c. Diasumsikan bahwa pola data yang ada dari data masa lalu akan berkelanjutan dimasa yang akan datang.

Adapun jenis data-data yang ada di lapangan adalah:

a. Musiman (Seasonal)

b. Horizontal (Stationary)

c. Siklus (Cylikal)

d. Trend

Dalam menyusun ramalan, terdapat 2 macam analisis yang dapat digunakan yaitu:

1. Analisi deret waktu(time series), merupakan analisis antara variabel yang dicari dengan variabel waktu 
2. Analisis Cross Section atau sebab akibat (causal method), merupakan analisis variabel yang dicari dengan variabel bebas atau yang mempengaruhi.

Ada dua pendekatan untuk melakukan peramalan dengan menggunakan analisis deret waktu dengan metode regresi sederhana yaitu:

1. Analisis deret waktu untuk regresi sederhana linier

2. Analisis deret untuk regresi sederhana yang non linier

Untuk menjelaskan hubungan kedua metode tersebut digunakan notasi matematis sebagai berikut:

$$
\mathrm{Y}=\mathrm{a}+\mathrm{bX}
$$

Dimana:

$\mathrm{Y}=$ Variabel Response atau Variabel Akibat (Dependent)

$\mathrm{X}=$ Variabel Predictor atau Variabel Faktor Penyebab (Independent)

$\mathrm{a}=$ konstanta

$\mathrm{b}=$ koefisien regresi (kemiringan); besaran response yang ditimbulkan oleh predictor.

Nilai-nilai a dan b dapat dihitung dengan menggunakan Rumus dibawah ini :

$$
\begin{aligned}
& \mathrm{a}=\frac{(\Sigma \mathrm{y})\left(\Sigma \mathrm{x}^{2}\right)-(\Sigma \mathrm{x})(\Sigma \mathrm{xy})}{\mathrm{n}\left(\Sigma \mathrm{x}^{2}\right)-(\Sigma \mathrm{x})^{2}} \\
& \mathrm{~b}=\frac{\mathrm{n}(\Sigma \mathrm{xy})-(\Sigma \mathrm{x})(\Sigma \mathrm{y})}{\mathrm{n}\left(\Sigma \mathrm{x}^{2}\right)-(\Sigma \mathrm{x})^{2}}
\end{aligned}
$$

Dalam studi ini, Y adalah jumlah produksi pada tahun yang dicari (tahun 2025) dan X adalah perubahan waktu dari tahun saat penelitian dilakukan (tahun 2014) sampai tahun yang dicari (2025).

\section{Metode Analisis Aspek Fisik dan Lingkungan}

Analisis aspek fisik dan lingkungan menggunakan metoda sesuai Permen PU No. 20/PRT/2007 tentang Pedoman Teknik Analisis Aspek Fisik dan Lingkungan, Ekonomi, serta Sosial Budaya dalam Penyusunan Rencana Tata Ruang. Analisis fisik dan lingkungan wilayah atau kawasan bertujuan untuk mengenali karakteristik sumber daya alam tersebut, dengan menelaah kemampuan dan kesesuaian lahan, agar penggunaan lahan dalam pengembangan wilayah dan atau kawasan dapat dilakukan secara optimal dengan tetap memperhatikan keseimbangan ekosistem. Gambar 1 berikut merupakan bagan alir analisis aspek fisik dan lingkungan. 


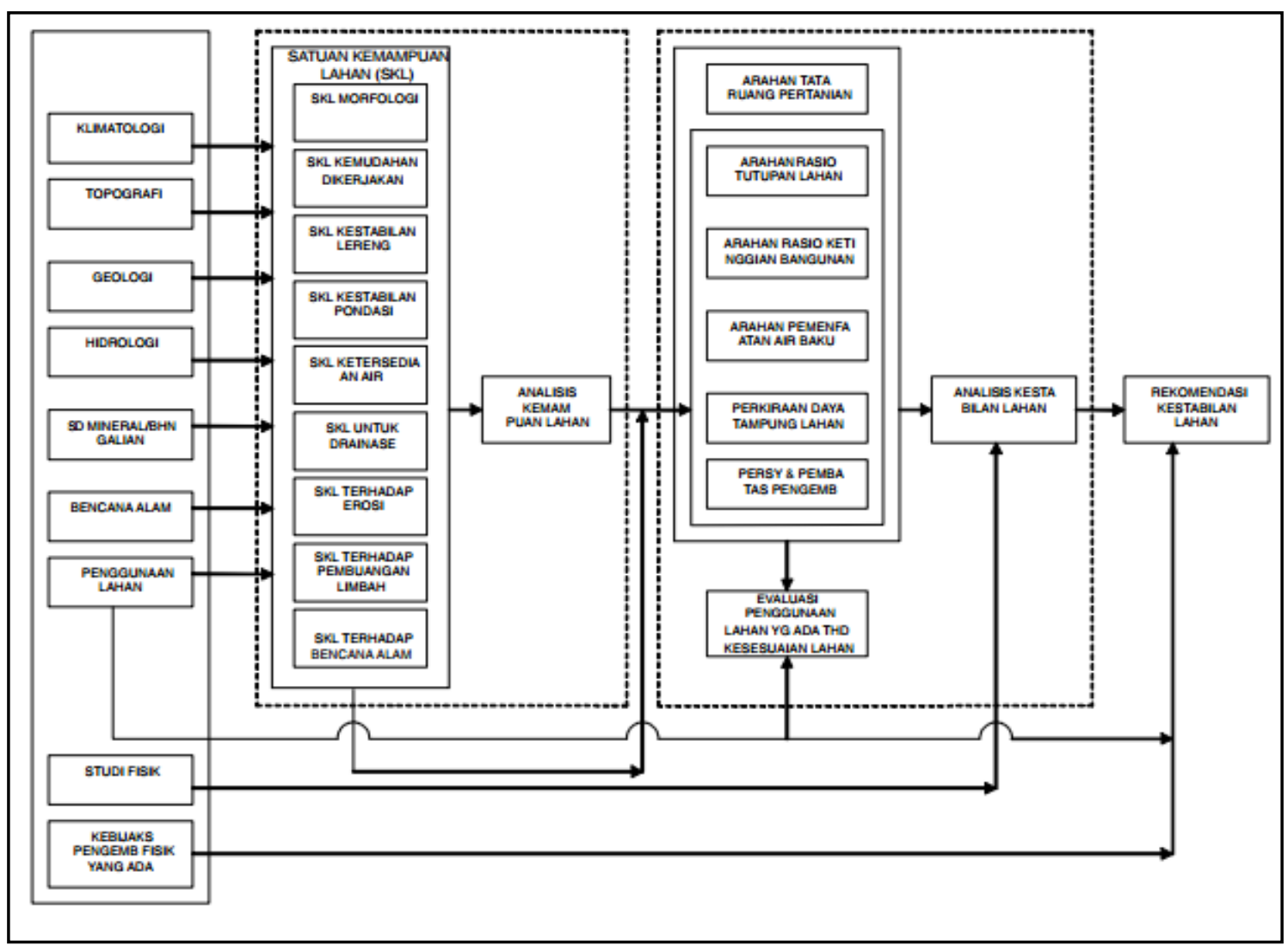

Sumber: Permen PU No. 20/PRT/2007

\section{Gambar 1. Bagan Alur Analisis Aspek Fisik dan Lingkungan}

Kesesuaian lahan yang dikeluarkan pada penelitian ini mencakup kesesuaian lahan untuk:

1. Kawasan lindung

2. Kawasan permukiman dan industri

3. Kawasan peruntukan hutan

4. Manggrove dan perikanan air payau

5. Penggembalaan ternak

6. Pertanian semusim lahan basah

7. Tambang dan lereng terjal

8. Tanaman semusim Lahan kering

9. Tanaman tahunan

\section{Satuan Kemampuan Lahan Provinsi Sumatera Utara}

\section{SKL Morfologi}

Dilihat dari peta SKL morfologi Provinsi Sumatera Utara, kemampuan lahan dari morfologi umumnya rendah dan kurang. Hanya sebagian wilayah yang memiliki kondisi morfologi tinggi. Hal ini menujukan bahwa umumnya kondisi morfologis tidak kompleks. Lebih lanjut, kondisi demikian menunjukkan bahwa Provinsi Sumatera memiliki kondisi tanah yang datar dan mudah dikembangkan sebagai tempat permukiman dan budi daya. Gambar 2 menyajikan kondisi SKL Morfologi di Provinsi Sumatera Utara. 


\section{SKL Kemudahan Dikerjakan}

Peta SKL Kemudahan Dikerjakan Provinsi Sumatera Utara dapat dilihat pada gambar 3. Dari pera tersebut terlihat bahwa di bagian timur umumnya sangat tinggi sementara bagian tengah. Kondisi ini berarti bahwa bagian timur memiliki kondisi lahan yang mudah untuk digali/dimatangkan dalam proses pembangunan/pengembangan kawasan.

\section{SKL Kestabilan Lereng}

SKL Kestabilan Lereng Provinsi Sumatera Utara dapat dilihat pada gambar 4. Pada bagian timur, kestabilan lereng dalam kondisi sedang yang berarti kondisi wilayah tidak begitu stabil. sedangkan di bagian tengah dan barat, kondisi kestabilan lerengnya rendah. Sehingga dapat dikatakan bahwa kestabililan lahan dilihat dari tingkat kemiringan lereng di lahan tersebut. Ketidakstabilan lereng menyebabkan daerah rawan longsor dan mudah bergerak sehingga tidak aman untuk didirikan bangunan dan dikembangkan menjadi kawasan permukiman dan budidaya.

\section{SKL Kestabilan Pondasi}

Peta SKL Kestabilan Pondasi Provinsi Sumatera Utara dapat dilihat pada gambar 5. Kestabilan pondasi di Provinsi Sumatera Utara pada umumnya tinggi dan sangat tinggi terutama di bagian timur dan sedikit di bagian barat. Hal ini menunjukkan bahwa wilayah tersebut akan stabil untuk pondasi bangunan apa saja atau untuk segala jenis pondasi. Di bagian tengah umumnya rendah dan sangat rendah berarti wilayah tersebut kurang stabil untuk berbagai bangunan. 


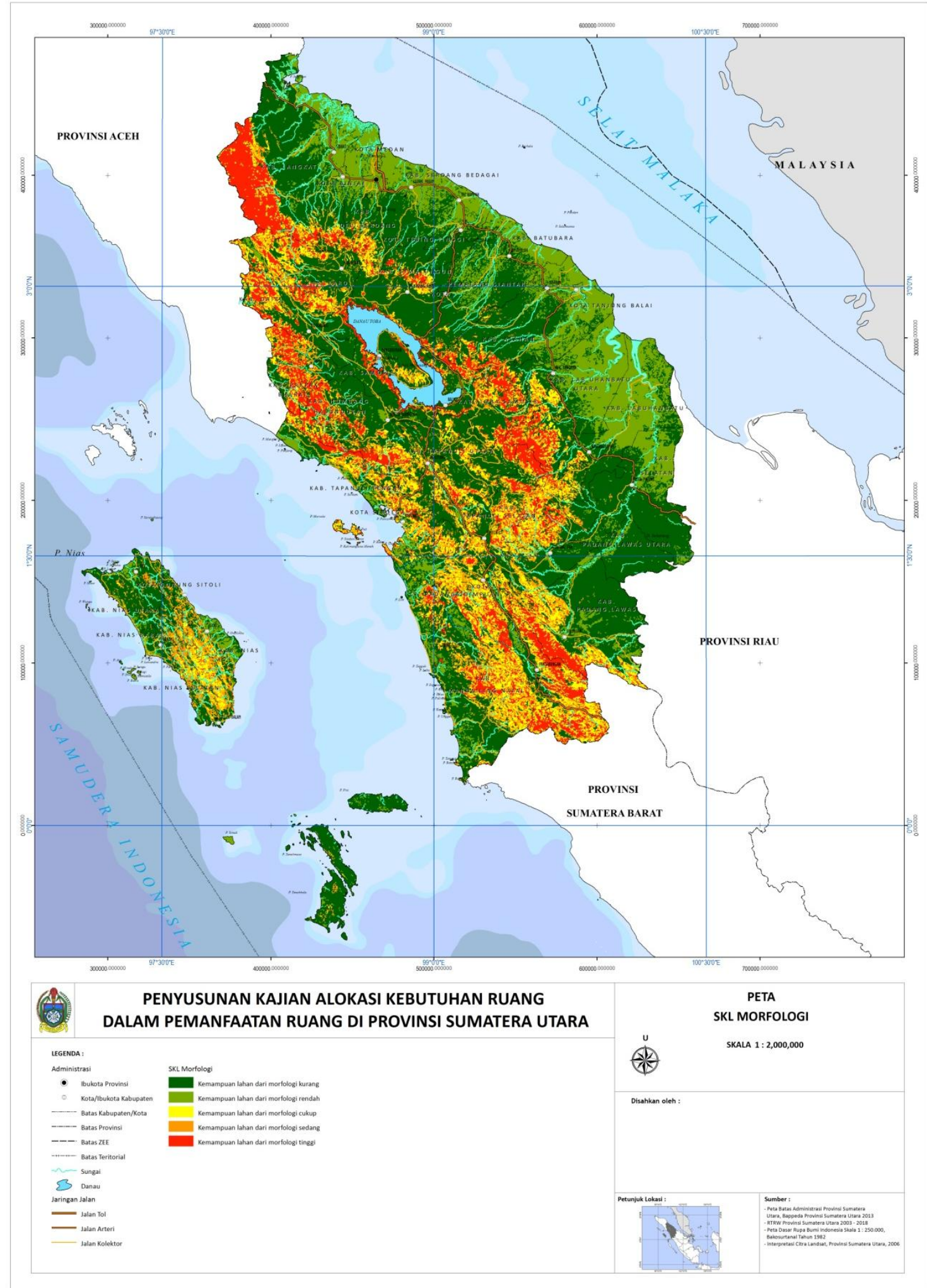

Gambar 2. SKL Morfologi Provinsi Sumatera Utara 


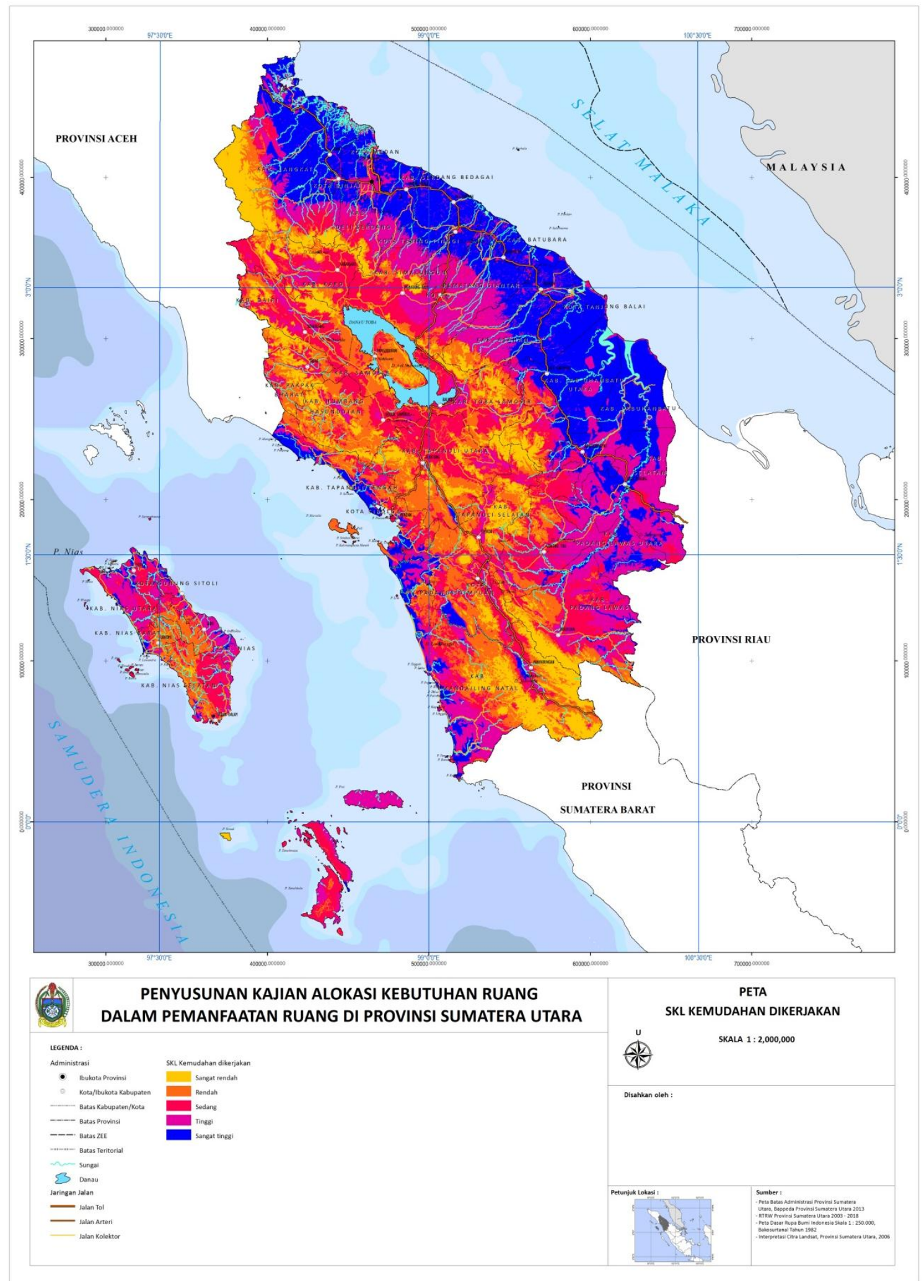

Gambar 3. SKL Kemudahan Dikerjakan Provinsi Sumatera Utara 


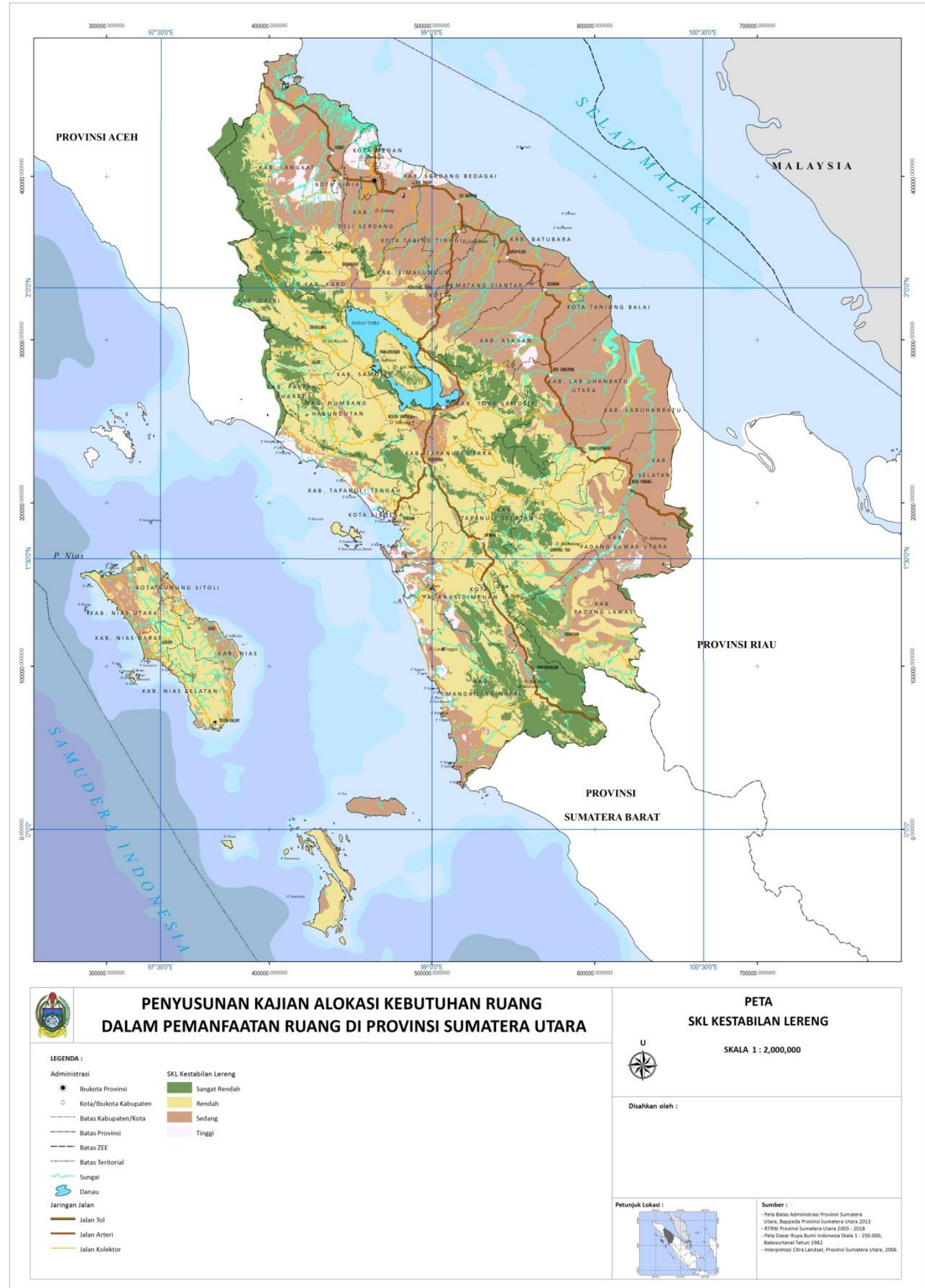

Gambar 4. SKL Kestabilan Lereng Provinsi Sumatera Utara 


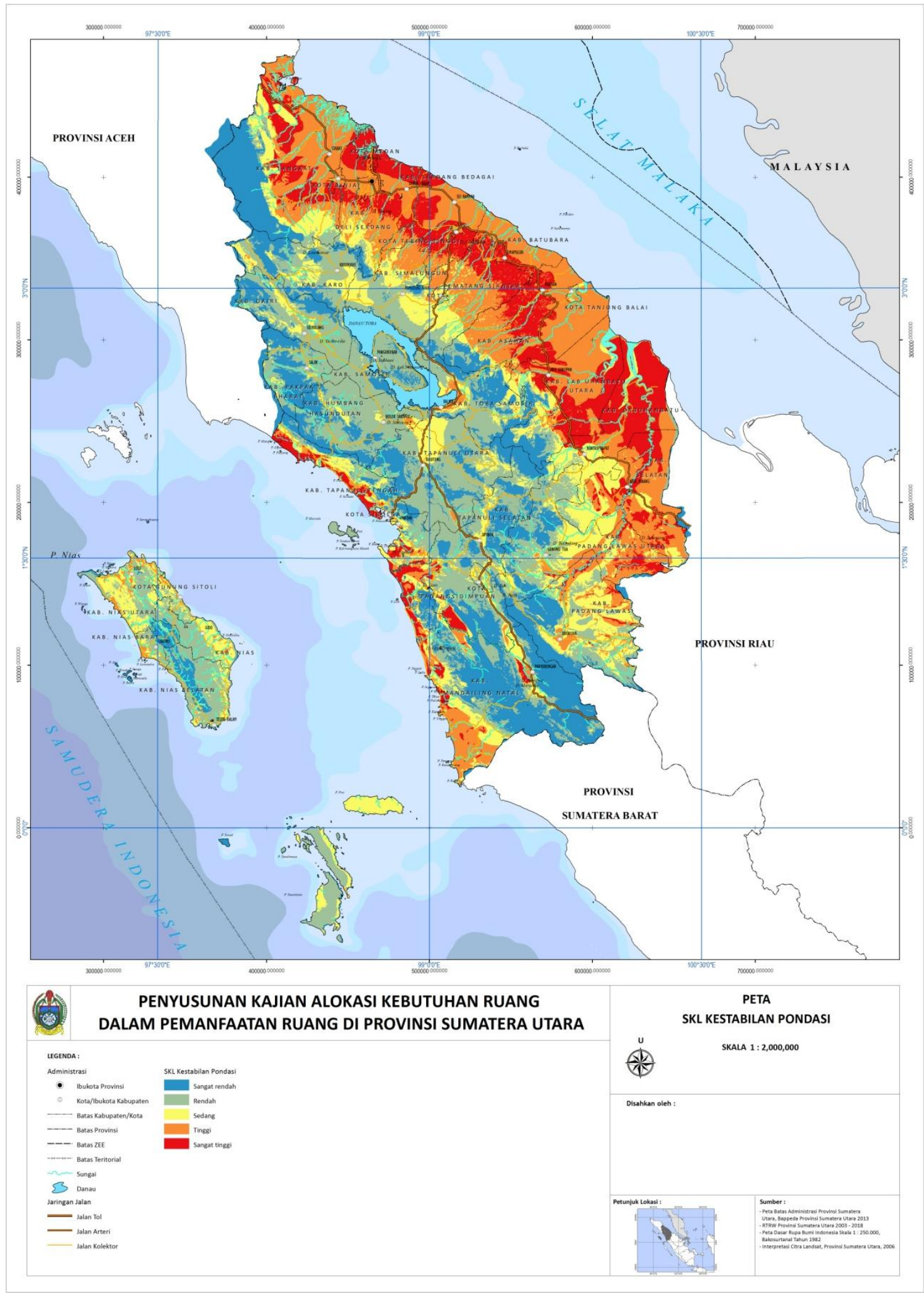

Gambar 5. SKL Kestabilan Pondasi Provinsi Sumatera Utara 


\section{Kajian Alokasi Kebutuhan Ruang di Provinsi Sumatera Utara}

Proyeksi Produksi Tanaman Padi, Palawija, dan Holtikultura di Provinsi Sumatera Utara Sampai Tahun 2025

Untuk mendapatkan besar proyeksi produksi tanaman padi, palawija dan holtikulutra, digunakan metoda regresi dengan rumus sebagai berikut:

$$
\mathrm{Y}=\mathrm{a}+\mathrm{bX}
$$

Dimana :

$\mathrm{Y}=$ Variabel Response atau Variabel Akibat (Dependent) dalam studi ini adalah jumlah produksi

$\mathrm{X}=$ Variabel Predictor atau Variabel Faktor Penyebab (Independent) dalam studi ini adalah perubahan waktu

$\mathrm{a}=$ konstanta

$\mathrm{b}$ = koefisien regresi (kemiringan); besaran Response yang ditimbulkan oleh Predictor.

Nilai-nilai a dan $\mathrm{b}$ dapat dihitung dengan menggunakan rumus:

$$
\begin{aligned}
& \mathrm{a}=\frac{(\Sigma \mathrm{y})\left(\Sigma \mathrm{x}^{2}\right)-(\Sigma \mathrm{x})(\Sigma \mathrm{xy})}{\mathrm{n}\left(\Sigma \mathrm{x}^{2}\right)-(\Sigma \mathrm{x})^{2}} \\
& \mathrm{~b}=\frac{\mathrm{n}(\Sigma \mathrm{xy})-(\Sigma \mathrm{x})(\Sigma \mathrm{y})}{\mathrm{n}\left(\Sigma \mathrm{x}^{2}\right)-(\Sigma \mathrm{x})^{2}}
\end{aligned}
$$

Dimana:

$\mathrm{y} \quad=$ data jumlah produksi yang didapat dari tahun 2000-2014

$\mathrm{x} \quad=$ tahun

$\mathrm{n} \quad=$ jumlah tahun data yang dijadikan dasar peramalan.

Dalam hal ini $\mathrm{n}$ berjumlah 6 karena tahun data produksi yang digunakan ada 6 yaitu dari tahun 2007-2012

a. Padi

Berdasarkan hasil analisis hingga tahun 2025 kebutuhan padi di Provinsi Sumatera Utara sebesar 3.879 .772 ton. Tabel 1 berikut menyajikan hasil proyeksi kebutuhan produksi padi di Provinsi Sumatera Utara hingga tahun 2025.

Tabel 1. Proyeksi Produksi Padi di Sumatera Utara Tahun 2015-2025

\begin{tabular}{ccc}
\hline No & Tahun & Produksi (Ton) \\
\hline 1 & 2015 & 3.630 .326 \\
2 & 2020 & 3.755 .049 \\
3 & 2025 & 3.879 .772 \\
\hline
\end{tabular}

b. Jagung

Berdasarkan hasil analisis hingga tahun 2025 kebutuhan jagung di Provinsi Sumatera Utara sebesar 2.228.172 ton. Tabel 2 berikut menyajikan hasil proyeksi kebutuhan produksi jagung di Provinsi Sumatera Utara hingga tahun 2025. 
Tabel 2. Proyeksi Produksi Jagung di Provinsi Sumatera Utara Tahun 2015-2025

\begin{tabular}{ccc}
\hline No & Tahun & Produksi (Ton) \\
\hline 1 & 2015 & 1.535 .158 \\
2 & 2020 & 1.881 .665 \\
3 & 2025 & 2.228 .172 \\
\hline
\end{tabular}

\section{c. Kedelai}

Berdasarkan hasil analisis hingga tahun 2025 kebutuhan kedelai di Provinsi Sumatera Utara sebesar 5.666 ton. Tabel 3 berikut menyajikan hasil proyeksi kebutuhan produksi kedelai di Provinsi Sumut hingga tahun 2025. Hasil proyeksi menunjukkan bahwa produksi kedelai diproyeksikan terus menurun hingga tahun 2025.

Tabel 3. Proyeksi Produksi Kedelai di Provinsi Sumatera UtaraTahun 2015-2025

\begin{tabular}{ccc}
\hline No & Tahun & Produksi (Ton) \\
\hline 1 & 2015 & 8.187 \\
2 & 2020 & 6.926 \\
3 & 2025 & 5.666 \\
\hline
\end{tabular}

\section{d. Kacang Tanah}

Berdasarkan hasil analisis hingga tahun 2025 kebutuhan kacang tanah di Provinsi Sumatera Utara sebesar $-1.902,89$ ton atau mengalami kekurangan. Tabel 4 berikut menyajikan hasil proyeksi kebutuhan produksi Kacang Tanah di Provinsi Sumatera Utara hingga tahun 2025.

Tabel 4. Proyeksi Produksi Kacang Tanah di Provinsi Sumatera UtaraTahun 2013-2025

\begin{tabular}{ccc}
\hline No & Tahun & Produksi (Ton) \\
\hline 1 & 2015 & $9.074,75$ \\
2 & 2020 & $3.585,93$ \\
3 & 2025 & $-1.902,89$ \\
\hline
\end{tabular}

\section{e. Ubi Kayu}

Berdasarkan hasil analisis hingga tahun 2025 kebutuhan Ubi Kayu di Provinsi Sumatera Utara sebesar $1.891 .939,85$ Ton. Tabel 5 berikut menyajikan hasil proyeksi kebutuhan produksi Ubi Kayu di Provinsi Sumatera Utara hingga tahun 2025.

Tabel 5. Proyeksi Produksi Ubi Kayu di Provinsi Sumatera UtaraTahun 2013-2025

\begin{tabular}{ccc}
\hline No & Tahun & Produksi (Ton) \\
\hline 1 & 2015 & $1.277 .512,15$ \\
2 & 2020 & $1.584 .726,00$ \\
3 & 2025 & $1.891 .939,85$ \\
\hline
\end{tabular}




\section{Kajian Alokasi Kebutuhan Ruang di Provinsi Sumatera Utara}

\section{f. Kacang Hijau}

Berdasarkan hasil analisis hingga tahun 2025 kebutuhan Kacang Hijau di Provinsi Sumatera Utara sebesar -7.038,30 ton, dimana kondisi ini terus menurun dari tahun 2015 hingga 2025. Tabel 6 berikut menyajikan hasil proyeksi kebutuhan produksi Kacang Hijau di Provinsi Sumatera Utara hingga tahun 2025.

Tabel 6. Proyeksi Produksi Kacang Hijau di Sumatera UtaraTahun 2015-2025

\begin{tabular}{ccc}
\hline No & Tahun & Produksi (Ton) \\
\hline 1 & 2015 & 401,46 \\
2 & 2020 & $-3.318,42$ \\
3 & 2025 & $-7.038,30$ \\
\hline
\end{tabular}

g. Ubi Jalar

Berdasarkan hasil analisis hingga tahun 2025 kebutuhan Ubi Jalar di Provinsi Sumatera Utara sebesar $237.598,45$ ton. Tabel 7 berikut menyajikan hasil proyeksi kebutuhan produksi Ubi Jalar di Provinsi Sumatera Utara hingga tahun 2025.

Tabel 7. Proyeksi Produksi Ubi Jalar di Provinsi Sumatera UtaraTahun 2015-2025

\begin{tabular}{ccc}
\hline No & Tahun & Produksi (Ton) \\
\hline 1 & 2015 & $183.953,55$ \\
2 & 2020 & $210.776,00$ \\
3 & 2025 & $237.598,45$ \\
\hline
\end{tabular}

h. Cabe

Berdasarkan hasil analisis hingga tahun 2025 kebutuhan Cabe di Provinsi Sumatera Utara sebesar 585.396 ton. Tabel 8 berikut menyajikan hasil proyeksi kebutuhan produksi Cabe di Provinsi Sumatera Utara hingga tahun 2025.

Tabel 8. Proyeksi Produksi Tanaman Cabe di Provinsi Sumatera Utara Tahun 2015-2025

\begin{tabular}{ccc}
\hline No & Tahun & Produksi (Ton) \\
\hline 1 & 2015 & 325.676 \\
2 & 2020 & 455.536 \\
3 & 2025 & 585.396 \\
\hline
\end{tabular}

\section{i. Kubis}

Berdasarkan hasil analisis hingga tahun 2025 kebutuhan Kubis di Provinsi Sumatera Utara sebesar 187.508 ton. Tabel 9 berikut menyajikan hasil proyeksi kebutuhan produksi Kubis di Provinsi Sumatera Utara hingga tahun 2025. 
Tabel 9. Proyeksi Produksi Tanaman Kubis di Provinsi Sumatera Utara Tahun 2015-2025

\begin{tabular}{ccc}
\hline No & Tahun & Produksi (Ton) \\
\hline 1 & 2015 & 187.545 \\
2 & 2020 & 187.526 \\
3 & 2025 & 187.508 \\
\hline
\end{tabular}

\section{j. Kentang}

Berdasarkan hasil analisis hingga tahun 2025 kebutuhan Kentang di Provinsi Sumatera Utara sebesar 195.240 ton. Tabel 10 berikut menyajikan hasil proyeksi kebutuhan produksi Kentang di Provinsi Sumatera Utara hingga tahun 2025.

Tabel 10. Proyeksi Produksi Kentang di Provinsi Sumatera Utara Tahun 2015-2025

\begin{tabular}{ccc}
\hline No & Tahun & Produksi (Ton) \\
\hline 1 & 2015 & 147.640 \\
2 & 2020 & 171.440 \\
3 & 2025 & 195.240 \\
\hline
\end{tabular}

\section{k. Semangka}

Berdasarkan hasil analisis hingga tahun 2025 kebutuhan Semangka di Provinsi Sumatera Utara sebesar 240.493 ton. Tabel 11 berikut menyajikan hasil proyeksi kebutuhan produksi Semangka di Provinsi Sumatera Utara hingga tahun 2025.

Tabel 11. Proyeksi Produksi Tanaman Semangka di Provinsi Sumatera Utara Tahun 2015-2025

\begin{tabular}{ccc}
\hline No & Tahun & Produksi (Ton) \\
\hline 1 & 2015 & 124.376 \\
2 & 2020 & 182.435 \\
3 & 2025 & 240.493 \\
\hline
\end{tabular}

\section{m. Tomat}

Berdasarkan hasil analisis hingga tahun 2025 kebutuhan Tomat di Provinsi Sumatera Utara sebesar 196.375 ton. Tabel 12 berikut menyajikan hasil proyeksi kebutuhan produksi Tomat di Provinsi Sumatera Utara hingga tahun 2025.

Tabel 12. Proyeksi Produksi Tanaman Tomat di Provinsi Sumatera Utara Tahun 2015-2025

\begin{tabular}{ccc}
\hline No & Tahun & Produksi (Ton) \\
\hline 1 & 2015 & 126.253 \\
2 & 2020 & 161.314 \\
3 & 2025 & 196.375 \\
\hline
\end{tabular}


n. Petai/Sawi

Berdasarkan hasil analisis hingga tahun 2025 kebutuhan Petai/Sawi di Provinsi Sumatera Utara sebesar 38.082 ton. Tabel 13 berikut menyajikan hasil proyeksi kebutuhan produksi Petai/Sawi di Provinsi Sumatera Utara hingga tahun 2025.

Tabel 13. Proyeksi Produksi Tanaman Petai/Sawi di Provinsi Sumatera Utara Tahun 2015- 2025

\begin{tabular}{ccc}
\hline No & Tahun & Produksi (Ton) \\
\hline 1 & 2015 & 59.708 \\
2 & 2020 & 48.895 \\
3 & 2025 & 38.082 \\
\hline
\end{tabular}

\section{Kacang Panjang}

Berdasarkan hasil analisis hingga tahun 2025 kebutuhan Kacang Panjang di Provinsi Sumatera Utara sebesar 62.490 ton. Tabel 14 berikut menyajikan hasil proyeksi kebutuhan produksi Kacang Panjang di Provinsi Sumatera Utara hingga tahun 2025.

Tabel 14. Proyeksi Produksi Tanaman Kacang Panjang di Provinsi Sumatera Utara Tahun 2015-2025

\begin{tabular}{ccc}
\hline No & Tahun & Produksi (Ton) \\
\hline 1 & 2015 & 50.424 \\
2 & 2020 & 56.457 \\
3 & 2025 & 62.490 \\
\hline
\end{tabular}

\section{p. Buncis}

Berdasarkan hasil analisis hingga tahun 2025 kebutuhan Buncis di Provinsi Sumatera Utara sebesar 97.127 ton. Tabel 15 berikut menyajikan hasil proyeksi kebutuhan produksi Buncis di Provinsi Sumatera Utara hingga tahun 2025.

Tabel 15. Proyeksi Produksi Tanaman Buncis di Sumatera Utara Tahun 2015-2025

\begin{tabular}{ccc}
\hline No & Tahun & Produksi (Ton) \\
\hline 1 & 2015 & 63.127 \\
2 & 2020 & 80.127 \\
3 & 2025 & 97.127 \\
\hline
\end{tabular}

\section{Luas Tanam Lahan untuk Produksi Tanaman Padi, Palawija, dan Holtikultura}

Dengan menggunakan data produktivitas, dapat dicari luas tanam yang diperlukan untuk menghasilkan buah-buahan atau sayuran yang diproduksi. Data produktivitas didapat dari rata-rata produktivitas dari tahun 2000 sampai tahun 2012. Luas tanam untuk padi, palawija dan holtikultura dapat dilihat pada Tabel 16 dan 17. 
Tabel 16. Proyeksi Produksi Luas Tanaman Padi dan Palawija di Provinsi Sumatera Utara Tahun 2025

\begin{tabular}{clccc}
\hline No & \multicolumn{1}{c}{ Komoditas } & $\begin{array}{c}\text { Rata-rata Produktivitas } \\
(\text { Ku/Ha) }\end{array}$ & Produksi (Ton) & Luas Panen (Ha) \\
\hline 1 & Padi & 43,74 & 3.879 .772 & $886.945,45$ \\
2 & Jagung & 39,37 & 2.228 .172 & $566.023,09$ \\
3 & Kedelai & 11,08 & 5.666 & $5.115,79$ \\
4 & Kacang tanah & 11,11 & $-1.902,89$ & $-171, .54$ \\
5 & Kacang hijau & 10,49 & $-7.038,30$ & $-6.712,20$ \\
6 & Ubi kayu & 177,99 & $1.891 .939,85$ & $106.295,19$ \\
7 & Ubi jalar & 104,63 & $237.598,45$ & $22.708,61$ \\
& & Jumlah & & $\mathbf{1 . 5 8 7 . 0 8 8}$ \\
\hline
\end{tabular}

Tabel 17. Luas Tanaman Sayuran di Provinsi Sumatera Utara Tahun 2025

\begin{tabular}{clccc}
\hline No & \multicolumn{1}{c}{ Komoditas } & Produksi (ton) & $\begin{array}{c}\text { Rata-rata } \\
\text { produktivitas (ton/ha) }\end{array}$ & Luas lahan (ha) \\
\hline 1 & Cabe & 585.396 & 11,11 & $52.690,91$ \\
2 & Kubis & 187.508 & 23,8 & $7.878,48$ \\
3 & Kentang & 195.240 & 17,24 & $11.324,83$ \\
4 & Semangka & 240.493 & 23,34 & $10.303,91$ \\
5 & Tomat & 196.375 & 27,1 & $7.246,33$ \\
6 & Petai/sawi & 38.082 & 10,87 & $3.503,39$ \\
7 & Kacang panjang & 62.490 & 10,40 & $6.008,67$ \\
8 & Buncis & 97.127 & 14,52 & $6.689,16$ \\
& & Jumlah & & $\mathbf{1 0 5 . 6 4 5 , 6 7}$ \\
\hline
\end{tabular}

Proyeksi Kebutuhan Konsumsi Pangan Provinsi Sumatera Utara Menurut Kelompok Pangan sampai Tahun 2025

Pada grand design ketahanan pangan Provinsi Sumatera Utara tahun 2012-2015, dapat dilihat sasaran konsumsi pangan penduduk Provinsi Sumatera Utara hingga tahun 2025, yaitu untuk beras sebanyak $104 \mathrm{~kg} / \mathrm{kapita} /$ tahun, jagung sebanyak 3,3 $\mathrm{kg} / \mathrm{kapita} /$ tahun, terigu sebanyak $2,5 \mathrm{~kg} / \mathrm{kapita} / \mathrm{tahun}$, umbi-umbian sebanyak 36,5 $\mathrm{kg} / \mathrm{kapita} /$ tahun, daging sebanyak $15,25 \mathrm{~kg} / \mathrm{kapita} / \mathrm{tahun}$, dan lainnya. Tabel 18 menyajikan sasaran konsumsi pangan utama tahun 2013 hingga 2025.

Tabel 18. Sasaran Konsumsi Pangan Utama Tahun 2013 dan 2025

\begin{tabular}{lcccccc}
\hline \multirow{2}{*}{ Komoditas } & $\mathbf{2 0 1 3}$ & $\mathbf{2 0 1 4}$ & $\mathbf{2 0 1 5}$ & $\mathbf{2 0 1 6}$ & $\mathbf{2 0 1 7}$ & $\mathbf{2 0 2 5}$ \\
\cline { 2 - 6 } & \multicolumn{7}{c}{$\mathbf{( K g / k a p i t a / t a h u n )}$} \\
\hline Beras & 131,46 & 129,48 & 127,50 & 125,52 & 112 & 104 \\
Jagung & 2,6 & 2,5 & 3,3 & 3,3 & 3,3 & 3,3 \\
Terigu & 6,4 & 6,1 & 5,5 & 5,5 & 5,5 & 2,5 \\
Umbi- & 28,3 & 29,3 & 36,5 & 36,5 & 36,5 & 36,5 \\
umbian & 9,9 & 10,4 & 15,25 & 15,25 & 15,25 & 15,25 \\
Daging & 10,5 & 10,9 & 11,25 & 11,25 & 11,25 & 11,25 \\
Telur & 2,4 & 2,5 & 23,25 & 23,25 & 23,25 & 28,25 \\
Susu & 8,0 & 8,2 & 9,09 & 9,09 & 9,09 & 9,09 \\
Kedelai & 9,5 & 9,6 & 10,95 & 10,95 & 10,95 & 10,95 \\
Gula Pasir & 17,0 & 28,0 & 38,80 & 48,80 & 58,80 & 58,80 \\
Sayuran & 32,0 & 33,2 & 32,45 & 32,45 & 32,45 & 32,45 \\
Buah & & &
\end{tabular}

Sumber: Grand Design Ketahanan Pangan Prov. Sumut tahun 2012-2025 
Proyeksi penduduk Provinsi Sumatera Utara dihitung menggunakan metode regresi bunga berganda dengan rumus berikut:

$$
\mathrm{Pt}=\mathrm{Po}(1+\mathrm{r})^{\mathrm{t}}
$$

Dengan rumus tersebut dapat dilihat bahwa pada tahun 2025, jumlah penduduk Provinsi Sumatera Utara mencapai 17.141.669 jiwa. Hasil proyeksi penduduk Kabupaten atau Kota di Provinsi Sumatera Utara terlihat di Tabel 19.

Tabel 19. Proyeksi Jumlah Penduduk per Kabupaten/Kota di Provinsi Sumatera Utara

\begin{tabular}{|c|c|c|c|c|c|c|c|}
\hline \multirow[t]{2}{*}{ No. } & \multirow[t]{2}{*}{ Kab/Kota } & LPP rata2 & $\begin{array}{l}\text { Penduduk } \\
\text { Tahun } \\
\text { Dasar } \\
(\mathbf{2 0 0 8 )}\end{array}$ & $\begin{array}{l}\text { Proyeksi } \\
2010\end{array}$ & $\begin{array}{l}\text { Proyeksi } \\
2015\end{array}$ & $\begin{array}{c}\text { Proyeksi } \\
2020\end{array}$ & $\begin{array}{l}\text { Proyeksi } \\
2025\end{array}$ \\
\hline & & $(\%)$ & (jiwa) & (jiwa) & (jiwa) & (jiwa) & (jiwa) \\
\hline 1 & Nias & $0,58 \%$ & 443.492 & 448.679 & 461.915 & 475.540 & 489.568 \\
\hline 2 & Mandailing Natal & $2,85 \%$ & 423.712 & 448.243 & 515.964 & 593.917 & 683.647 \\
\hline 3 & Tapanuli Selatan & $1,48 \%$ & 263.812 & 271.679 & 292.387 & 314.673 & 338.659 \\
\hline 4 & Tapanuli Tengah & $3,11 \%$ & 314.632 & 334.490 & 389.794 & 454.242 & 529.345 \\
\hline 5 & Tapanuli Utara & $0,68 \%$ & 267.595 & 271.235 & 280.554 & 290.192 & 300.162 \\
\hline 6 & Toba Samosir & $0,72 \%$ & 171.833 & 174.305 & 180.642 & 187.210 & 194.016 \\
\hline 7 & Labuhan Batu & $2,43 \%$ & 1.027 .964 & 1.078 .568 & 1.216 .247 & 1.371 .500 & 1.546 .571 \\
\hline 8 & Asahan & $1,53 \%$ & 688.529 & 709.759 & 765.743 & 826.142 & 891.306 \\
\hline 9 & Simalungun & $1,03 \%$ & 853.112 & 870.729 & 916.381 & 964.426 & 1.014 .990 \\
\hline 10 & Dairi & $1,22 \%$ & 271.983 & 278.647 & 296.029 & 314.496 & 334.115 \\
\hline 11 & Karo & $3,72 \%$ & 360.880 & 388.198 & 465.885 & 559.119 & 671.012 \\
\hline 12 & Deli Serdang & $3,35 \%$ & 1.738 .431 & 1.856 .815 & 2.189 .256 & 2.581 .217 & 3.043 .354 \\
\hline 13 & Langkat & $2,22 \%$ & 1.042 .523 & 1.089 .226 & 1.215 .343 & 1.356 .062 & 1.513 .075 \\
\hline 14 & Nias Selatan & $-0,84 \%$ & 272.848 & 268.301 & 257.263 & 246.678 & 236.530 \\
\hline 15 & $\begin{array}{l}\text { Humbang } \\
\text { Hasundutan }\end{array}$ & $0,45 \%$ & 155.290 & 156.697 & 160.271 & 163.926 & 167.664 \\
\hline 16 & Pakpak Bharat & $4,72 \%$ & 41.062 & 45.029 & 56.706 & 71.410 & 89.928 \\
\hline 17 & Samosir & $2,43 \%$ & 131.549 & 138.011 & 155.591 & 175.410 & 197.753 \\
\hline 18 & Serdang Bedagai & $1,99 \%$ & 630.728 & 656.033 & 723.827 & 798.626 & 881.156 \\
\hline 19 & Batu Bara & - & 382.474 & - & - & - & - \\
\hline 20 & Padang Lawas Utara & - & 193.278 & - & - & - & - \\
\hline 21 & $\begin{array}{l}\text { Padang Lawas } \\
\text { Selatan }\end{array}$ & - & 185.209 & - & - & - & - \\
\hline 22 & $\begin{array}{l}\text { Labuhan Batu Utara } \\
\text { Labuhan Batu }\end{array}$ & - & - & - & - & - & - \\
\hline 23 & Selatan & - & - & - & - & - & - \\
\hline Tota & l Kabupaten & $1,87 \%$ & 9.860 .936 & 9.484 .645 & 10.539 .796 & 11.744 .788 & 13.122.849 \\
\hline 22 & Kota Sibolga & $2,05 \%$ & 94.614 & 98.528 & 109.037 & 120.667 & 133.537 \\
\hline 23 & Kota Tanjung Balai & $2,34 \%$ & 163.679 & 171.415 & 192.394 & 215.941 & 242.369 \\
\hline 24 & $\begin{array}{l}\text { Kota } \\
\text { Pematangsiantar }\end{array}$ & $1,21 \%$ & 238.773 & 244.598 & 259.790 & 275.926 & 293.064 \\
\hline 25 & Kota Tebing Tinggi & $1,22 \%$ & 141.059 & 144.522 & 153.556 & 163.155 & 173.354 \\
\hline 26 & Kota Medan & $1,12 \%$ & 2.102 .105 & 2.149 .386 & 2.272 .292 & 2.402 .227 & 2.539 .592 \\
\hline 27 & Kota Binjai & $2,13 \%$ & 252.652 & 263.528 & 292.812 & 325.349 & 361.502 \\
\hline 28 & $\begin{array}{l}\text { Kota } \\
\text { Padangsidimpuan }\end{array}$ & $2,26 \%$ & 188.499 & 197.097 & 220.348 & 246.342 & 275.402 \\
\hline & $\begin{array}{c}\text { Total Kota } \\
\text { Sumatera Utara }\end{array}$ & $\begin{array}{l}1,36 \% \\
1,62 \%\end{array}$ & $\begin{array}{c}\text { 3.181.381 } \\
13.042 .317 \\
\end{array}$ & $\begin{array}{c}3.269 .075 \\
12.753 .720 \\
\end{array}$ & $\begin{array}{c}3.500 .230 \\
14.040 .026\end{array}$ & $\begin{array}{c}3.749 .607 \\
15.494 .394 \\
\end{array}$ & $\begin{array}{c}4.018 .820 \\
17.141 .669 \\
\end{array}$ \\
\hline
\end{tabular}


Untuk mendapatkan jumlah kebutuhan komoditas pangan dalam satu tahun pada tahun 2025, digunakan jumlah penduduk pada tahun 2025. Oleh sebab itu ditemukan besar produksi pangan utama yang harus dihasilkan untuk memenuhi sasaran konsumsi pangan tahun 2025. Untuk komoditas beras dibutuhkan $1.782 .733 .576 \mathrm{~kg}$ beras selama setahun atau 1,8 juta ton beras. Untuk komoditas jagung diperlukan 56.567.507,7 kg pertahun atau 57 ribu ton selama setahun. Lebih jelasnya dapat dilihat pada Tabel 20.

Tabel 20. Proyeksi Kebutuhan Konsumsi Pangan di Provinsi Sumatera Utara Tahun 2025

\begin{tabular}{lccc}
\hline \multicolumn{1}{c}{ Komoditas } & Kg/Kapita/2025 & $\begin{array}{c}\text { Jumlah Penduduk Tahun } \\
\mathbf{2 0 2 5}\end{array}$ & $\begin{array}{c}\text { Kebutuhan Tahun } \\
\mathbf{2 0 2 5}(\mathbf{K g})\end{array}$ \\
\hline Beras & 104 & 17.141 .669 & 1.782 .733 .576 \\
Jagung & 3,3 & 17.141 .669 & $56.567 .507,7$ \\
Terigu & 2,5 & 17.141 .669 & $42.854 .172,5$ \\
Umbi-umbian & 35,5 & $17,141.669$ & $608.529 .249,5$ \\
Daging & 15,25 & $17.141,669$ & $261.410 .452,3$ \\
Telur & 11,25 & 17.141 .669 & $192.843 .776,3$ \\
Susu & 28,25 & 17.141 .669 & $484.252 .149,3$ \\
Kedelai & 9,09 & 17.141 .669 & $155.817 .771,2$ \\
Gula pasir & 10,95 & 17.141 .669 & $187.701 .275,6$ \\
Sayuran & 58,8 & 17.141 .669 & 1.007 .930 .137 \\
Buah & 32,45 & 17.141 .669 & $556.247 .159,1$ \\
& Total & & $\mathbf{5 . 3 3 6 . 8 8 7 . 2 2 6}$ \\
\hline
\end{tabular}

\section{Proyeksi Luas Areal Perkebunan di Provinsi Sumatera Utara}

Sektor perkebunan merupakan sub sektor yang menjadi penyumbang pendapatan daerah ketiga terbesar di Provinsi Sumatera Utara. Komoditi utama dari kegiatan perkebunan di Sumatera Utara adalah kelapa sawit, kelapa, karet, kopi, kulit manis, coklat, teh, tembakau, aren, pinang, dan tebu. Perkebunan yang terdapat di Sumatera Utara terdiri dari perkebunan rakyat, perkebunan pemerintah dan perkebunan swasta. Perkembangan luar areal perkebunan selama empat tahun (2006-2009) meningkat seluas 154.165,76 Ha dengan laju pertumbuhan rata-rata $1,63 \%$ pertahun. Perkembangan luas areal perkebunan Sumatera Utara dari tahun proyeksi tahun 2012 sampai dengan tahun 2025 dapat dilihat pada Tabel 21. Dari hasil proyeksi terlihat bahwa pada tahun 2025, luas areal perkebunan akan mencapai 2.483.449,80 ha.

Tabel 21. Perkiraan Perkembangan Luas Areal Perkebunan Tahun 2022-2025

\begin{tabular}{clcccc}
\hline \multirow{2}{*}{ No } & \multirow{2}{*}{ Jenis Tanaman } & \multicolumn{4}{c}{ Luas (Ha) } \\
\cline { 3 - 6 } & & $\mathbf{2 0 2 2}$ & $\mathbf{2 0 2 3}$ & $\mathbf{2 0 2 4}$ & $\mathbf{2 0 2 5}$ \\
\hline 1 & Perkebunan Rakyat & $1.207 .013,02$ & $1.217 .996,84$ & $1.229 .080,61$ & $1.240 .265,24$ \\
2 & Perkebunan Besar/Swasta & $715.521,69$ & $749.437,41$ & $784.960,75$ & $822.167,89$ \\
3 & BUMN/PTPN & $416.875,97$ & $418.251,66$ & $419.631,89$ & $421.016,68$ \\
& Jumlah Total & $\mathbf{2 . 3 3 9 . 4 1 0 , 6 7}$ & $\mathbf{2 . 3 8 5 . 6 8 5 , 9 1}$ & $\mathbf{2 . 4 3 3 . 6 7 3 , 2 5}$ & $\mathbf{2 . 4 8 3 . 4 4 9 , 8 0}$ \\
\hline Sumber: & RTRW Provinsi Sumatera Utara, 2013-2033 & &
\end{tabular}

Sumber: RTRW Provinsi Sumatera Utara, 2013-2033 


\section{Proyeksi Kebutuhan Permukiman di Perkotaan di Provinsi Sumatera Utara}

Proyeksi kebutuhan lahan untuk permukiman di Provinsi Sumatera Utara dilakukan dengan menggunakan data proyeksi dan kebijakan pada RTRW Provinsi Sumatera Utara tahun 2013-2033. Tabel 22 menyajikan hasil proyeksi luas areal permukiman tiap kabupaten atau kota di Provinsi Sumatera Utara. Hasil proyeksi menunjukkan bahwa kebutuhan lahan untuk permukiman di tahun 2025 diperkirakan seluas 210.293,97 ha.

Tabel 22. Perkiraan (Proyeksi) Luas Areal Permukiman di Tiap Kabupaten/Kota di Provinsi Sumatera Utara

\begin{tabular}{|c|c|c|}
\hline Kabupaten/ Kota & Pola Ruang & Luas (Ha) \\
\hline Tebingtinggi & Permukiman & $2.632,52$ \\
\hline Tanjung Balai & Permukiman & $2.540,63$ \\
\hline Medan & Permukiman & $25.046,32$ \\
\hline Labuhanbatu Selatan & Permukiman & $5.053,17$ \\
\hline Karo & Permukiman & $2.427,81$ \\
\hline Dairi & Permukiman & 833,78 \\
\hline Pak-Pak Bharat & Permukiman & 108,56 \\
\hline Padanglawas Utara & Permukiman & 288,89 \\
\hline Binjai & Permukiman & $5.382,29$ \\
\hline Deli Serdang & Permukiman & $38.996,02$ \\
\hline Padang Sidempuan & Permukiman & $1.928,30$ \\
\hline Padanglawas & Permukiman & $17.818,32$ \\
\hline Labuhanbatu Utara & Permukiman & $9.661,80$ \\
\hline Toba Samosir & Permukiman & $2.087,40$ \\
\hline Pematang Siantar & Permukiman & $3.930,089$ \\
\hline Gunung Sitoli & Permukiman & 371,53 \\
\hline Nias Barat & Permukiman & 597,50 \\
\hline Sibolga & Permukiman & 532,83 \\
\hline Langkat & Permukiman & $19.133,29$ \\
\hline Batubara & Permukiman & $2.788,54$ \\
\hline Samosir & Permukiman & $1.925,05$ \\
\hline Humbang Hasundutan & Permukiman & 398,13 \\
\hline Tapanuli Utara & Permukiman & $2.583,39$ \\
\hline Mandailing Natal & Permukiman & $7.355,43$ \\
\hline Tapanuli Tengah & Permukiman & $7.255,30$ \\
\hline Nias Utara & Permukiman & 670,63 \\
\hline Nias Selatan & Permukiman & $1.472,94$ \\
\hline Labuhanbatu & Permukiman & $3.006,56$ \\
\hline Tapanuli Selatan & Permukiman & $1.080,20$ \\
\hline Asahan & Permukiman & $15.780,36$ \\
\hline Simalungun & Permukiman & $11.585,95$ \\
\hline Nias & Permukiman & $1.560,04$ \\
\hline Serdang Bedagai & Permukiman & $13.460,40$ \\
\hline Jumlah & & $210.293,969$ \\
\hline
\end{tabular}

Sumber: RTRW Provinsi Sumatera Utara, 2013-2033 


\section{Analisis Kelebihan dan Kekurangan Luas Lahan}

Ketersediaan lahan dihitung dari hasil kesesuaian lahan. Luas kesesuaian lahan didapat dari kriteria SKL (Satuan Kemampuan Lahan). Dari kesesuaian lahan ditemukan lahan yang dapat dimanfaatkan untuk tanaman tahunan, pertanian semusim lahan basah, pertanian semusim lahan kering, dan sebagainya. Luas kesesuaian lahan di Provinsi Sumatera Utara terlihat di Tabel 23.

Tabel 23. Luas Kesesuaian Lahan Provinsi Sumatera Utara

\begin{tabular}{lc}
\hline \multicolumn{1}{c}{ Kesesuaian Lahan } & Luas (Ha) \\
\hline Kawasan Lindung & $484.957,11$ \\
Kawasan Permukiman Dan Industri & $24.655,43$ \\
Kawasan Peruntukan Hutan & $1.597 .550,65$ \\
Mangrove Dan Perikanan Air Payau & $235.723,03$ \\
Penggembalaan Ternak & $126.239,36$ \\
Pertanian Semusim Lahan Basah & $990.602,56$ \\
Pulau Kosong, Tambang dan Lereng Terjal & $3.780,73$ \\
Tanaman Semusim Lahan Kering & $1.516 .008,74$ \\
Tanaman Tahunan $\quad$ Jumlah & $\mathbf{2 . 1 4 8 . 9 4 1 , 8 8}$ \\
& $\mathbf{7 . 1 2 8 . 4 5 9}$ \\
\hline
\end{tabular}

\section{Analisis Tutupan Lahan Berdasarkan Citra Satelit 2013}

Menurut Lillesand dan Kiefer (1979), istilah penutup lahan berkaitan dengan jenis kenampakan yang ada di permukaan bumi. Sebagai contohnya adalah vegetasi, lahan kosong, dan lahan terbangun adalah penutup lahan. Konstruksi tersebut seluruhnya tampak secara langsung dari citra penginderaan jauh. Aplikasi penginderan jauh digunakan untuk mendapatkan informasi yang berkaitan dengan kondisi penutupan vegetasi dan atau penggunaan lahan saat ini (present land use/land cover) yang didapatkan dengan cara interpretasi citra satelit.

Di Provinsi Sumatera Utara, pada kenyataannya, lahan yang berdasarkan kesesuaian lahan dinyatakan tepat untuk kegunaan tertentu, belum tentu masih kosong atau digunakan untuk kegunaan tersebut. Lahan yang dinyatakan berdasarkan kesesuaian lahan tepat sebagai lahan untuk kawasan lindung seluas $484.957,10$ ha, ternyata sudah digunakan sebesar 995,02 ha untuk permukiman. Contoh lainnya pada lahan yang dinilai tepat untuk kawasan permukiman dan industri seluas 24.655,43 ha, namun sudah digunakan untuk hutan primer, hutan sekunder, perkebunan, dan lainnya seluas 8.910, 6 ha.

Pada kawasan peruntukan hutan yang seluas 1.597.550, 65 ha, lahan digunakan menjadi kebun campuran, perkebunan, permukiman, terjadi sebanyak $275.525,30$ ha. Pada kawasan yang tepat dijadikan kawasan mangrove sebesar 235.723,03 ha, telah terjadi perubahan guna lahan menjadi permukiman, kebun campuran, perkebunan, dan sawah sebesar 195.871,64 ha. Pada kawasan yang tepat dijadikan kawasan penggembalaan ternak sebesar 126.239, 36 ha, seluas 328,1 ha telah berubah menjadi permukiman.

Sementara yang lainnya adalah hutan, perkebunan, sawah, tegalan/ladang, dan lainnya. Pada lahan yang tepat dijadikan kawasan pertanian semusim lahan basah sebesar 990.602,56 ha, secara eksisting telah menjadi permukiman, perkebunan, kebun campuran, sebesar 509.979,76 ha. Sebanyak 29.740,32 ha berubah menjadi hutan primer dan sekunder. Sehingga kekurangan lahan untuk pertanian pada tahun 2025 sebesar 596.485,44 ha sebenarnya lebih besar karena lahan yang sesuai untuk pertanian sudah digunakan 


\section{Kajian Alokasi Kebutuhan Ruang di Provinsi Sumatera Utara}

menjadi permukiman, perkebunan dan kebun campuran. Pada lahan yang tepat dijadikan kawasan tanaman semusim lahan kering seluas 1.516.008,74 ha, telah menjadi hutan primer, hutan sekunder, permukiman, seluas 486.313, 07 ha. Pada lahan yang tepat dijadikan kawasan tanaman tahunan sebesar 2.148.941,88 ha telah menjadi hutan primer, hutan sekunder, permukiman dan sawah sebesar 456.316,53 ha. Lebih lengkapnya mengenai kondisi tutupan lahan di Provinsi Sumatera Utara terlihat di Gambar 6.

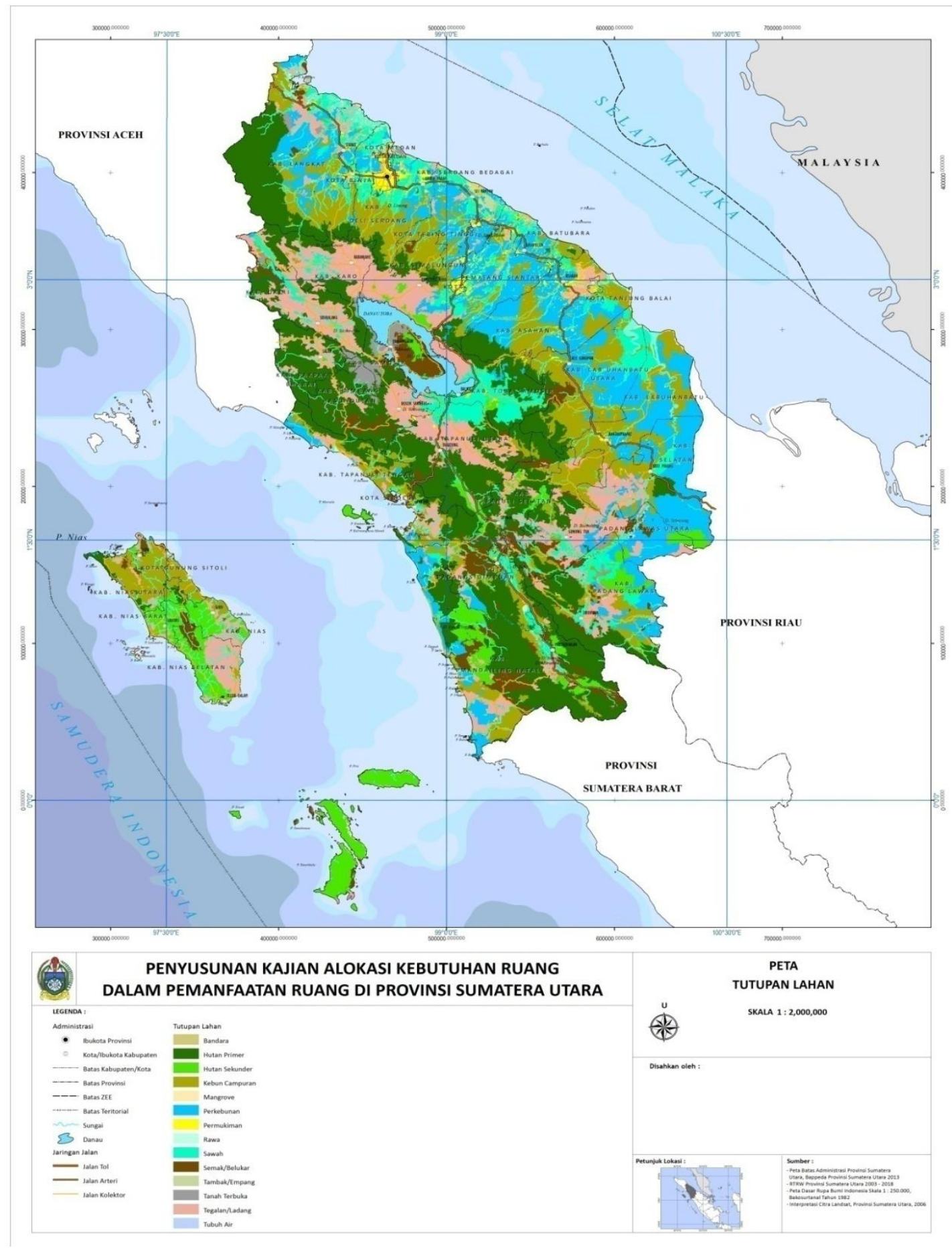

Gambar 6. Peta Tutupan Lahan Provinsi Sumatera Utara 


\section{Analisis Perbandingan Kebutuhan Lahan dengan Ketersediaan Lahan di Provinsi Sumatera Utara}

Hasil proyeksi luas tanam dan konsumsi pangan Provinsi Sumatera sampai tahun 2025 menunjukkan bahwa kebutuhan lahan padi dan palawija (dengan catatan produktivitas tetap) adalah seluas 1.587 .088 ha. Lahan pertanian cocok digunakan sebagai lahan pertanian semusim lahan basah dengan luas lahan pertanian lahan basah mencapai $990.602,56$ ha. Namun begitu, terjadi kekurangan lahan untuk pertanian pada tahun 2025 yaitu sebesar 596.485,44 ha. Tabel 24 menunjukkan perbandingan kondisi kebutuhan lahan pertanian dibandingkan ketersediaan lahan pertanian di Provinsi Sumatera Utara.

\section{Tabel 24. Perbandingan Kebutuhan Lahan Pertanian Dengan Ketersediaan Lahan Pertanian Berdasarkan Kesesuaian Lahan}

\begin{tabular}{ccc}
\hline $\begin{array}{c}\text { Kebutuhan lahan padi dan } \\
\text { palawija tahun 2025 (ha) }\end{array}$ & $\begin{array}{c}\text { Lahan pertanian berdasarkan } \\
\text { Kesesuaian Lahan (pertanian } \\
\text { semusim lahan basah) (ha) }\end{array}$ & $\begin{array}{c}\text { Kekurangan/kelebihan } \\
\text { (ha) }\end{array}$ \\
\hline 1.587 .088 & $990.602,56$ & $-596.485,44$ \\
\hline
\end{tabular}

Namun pada kenyataannya, hasil analisis tutupan lahan menemukan bahwa pada lahan yang tepat dijadikan kawasan pertanian semusim lahan basah sebesar 990.602,56 ha ini, secara eksisting telah menjadi permukiman, perkebunan, kebun campuran, sebesar 509.979,76 ha dan sebanyak 29.740,32 ha masih berupa hutan primer dan sekunder. Sehingga kekurangan lahan untuk pertanian pada tahun 2025 sebenarnya lebih besar dari $596.485,44$ ha.

Sementara itu, hasil proyeksi konsumsi pangan kebutuhan lahan untuk sayuran di tahun 2025 adalah 105.645,67 ha. Untuk menanam sayuran diperlukan lahan yang tepat untuk tanaman semusim kering dan tanah basah. Luas kesesuaian lahan untuk tanaman semusim tanah kering dan tanah basah berdasarkan kesesuaian lahan adalah 2.957.989,89 ha. Ini berarti berdasarkan kesesuaian lahan, pada tahun 2025 masih ada lahan sebesar 1.410.363,07 ha yang tepat bila ditanami sayuran. Lebih jelasnya dilihat pada Tabel 25 . Namun pada kenyataannya, hasil analisis peta tutupan lahan menemukan bahwa pada lahan yang tepat dijadikan kawasan tanaman semusim lahan kering seluas 1.516.008,74 ha ini, masih berupa hutan primer, hutan sekunder, dan sudah berupa permukiman seluas 486.313,07 ha.

Tabel 25. Perbandingan Kebutuhan Lahan Untuk Sayuran Dengan Ketersediaan Lahan Untuk Sayuran Semusim Tanah Kering dan Tanah Basah Berdasarkan SKL

\begin{tabular}{ccc}
\hline $\begin{array}{c}\text { Kebutuhan lahan sayuran } \\
\text { (ha) }\end{array}$ & $\begin{array}{c}\text { Lahan untuk tanaman semusim tanah } \\
\text { kering dan tanah basah berdasarkan } \\
\text { Kesesuaian Lahan (ha) }\end{array}$ & $\begin{array}{c}\text { Kekurangan/kelebihan } \\
\text { (ha) }\end{array}$ \\
\hline $105.645,67$ & $1.516 .008,74$ & $1.410 .363,07$ \\
\hline
\end{tabular}

Berdasarkan hasil proyeksi, ditemukan bahwa kebutuhan lahan untuk perumahan mencapai 634.241.753 ha. Berdasarkan analisa Kesesuaian Lahan, lahan yang tepat untuk permukiman adalah sebesar $24.655,43$ ha. Oleh sebab itu dapat dilihat bahwa berdasarkan Kesesuaian Lahan, pada tahun 2025 terjadi kekurangan lahan untuk perumahan sebesar 185.638,54 ha. Tabel 26 menyajikan perbandingan kebutuhan lahan untuk perumahan dengan ketersediaan lahan untuk permukiman. 
Tabel 26. Perbandingan Kebutuhan Lahan Untuk Perumahan Dengan Ketersediaan Lahan Untuk Permukiman Berdasarkan Kesesuaian Lahan

\begin{tabular}{ccc}
\hline $\begin{array}{c}\text { Kebutuhan lahan } \\
\text { permukiman (ha) }\end{array}$ & $\begin{array}{c}\text { Lahan untuk permukiman } \\
\text { berdasarkan Kesesuaian Lahan (ha) }\end{array}$ & $\begin{array}{c}\text { Kekurangan/kelebihan } \\
\text { (ha) }\end{array}$ \\
\hline $210.293,97$ & $24.655,43$ & $-185.638,54$ \\
\hline
\end{tabular}

Untuk perbandingan proyeksi konsumsi pangan, berdasarkan ketahanan pangan Provinsi Sumatera Utara sampai tahun 2025 dengan produktivitas padi, buah-buahan dan holtikultura, dihasilkan bahwa berdasarkan skenario ketahanan pangan diperlukan produksi padi sebanyak $1.782 .733 .576 \mathrm{~kg}$ beras untuk memenuhi kebutuhan padi untuk ketahanan pangan. Sementara itu, dari hasil proyeksi ditemukan bahwa padi yang akan dihasilkan pada tahun 2025 adalah sebesar 3.879 .772 ton atau $3.879 .772 .000 \mathrm{~kg}$ sehingga bila produktivitas tetap, maka pada tahun 2025, produksi padi Provinsi Sumatera Utara dapat memenuhi kebutuhan beras untuk ketahanan pangan asalkan besar lahan panen sampai tahun 2025 disediakan. Namun pada kenyataannya, seperti sudah dihitung bersama pada tabel 24, berdasarkan kesesuaian lahan, Provinsi Sumatera Utara mengalami kekurangan lahan yang sesuai untuk pertanian.

Berdasarkan skenario ketahanan pangan diperlukan produksi jagung sebanyak $56.567 .507,7 \mathrm{~kg}$ jagung. Sementara itu, dari hasil proyeksi, dengan asumsi produktivitas tetap, ditemukan bahwa pada tahun 2025 produksi jagung akan mencapai $2.228 .172 .000 \mathrm{~kg}$ asalkan kebutuhan lahannya tersedia atau luas lahan panennya mencukupi. Hal ini menunjukkan bahwa produksi jagung Provinsi Sumatera Utara pada tahun 2025 akan memenuhi kebutuhan jagung untuk ketahanan pangan dengan syarat besar kebutuhan lahannya disediakan. Berdasarkan kesesuaian lahan, masih banyak lahan di Provinsi Sumatera Utara yang sesuai dijadikan lahan bagi tanah kering dan tanah basah. Namun pada kenyataannya lahan yang sesuai ini masih berupa hutan primer dan hutan sekunder dan ada pula yang sudah menjadi permukiman.

Berdasarkan skenario ketahanan pangan diperlukan sebesar $1.007 .930 .137 \mathrm{~kg}$ sayuran. Berdasarkan hasil proyeksi, jumlah sayuran yang akan dihasilkan pada tahun 2025 adalah sebanyak $1.602 .711 .000 \mathrm{~kg}$. Sayuran yang masuk ke dalam hitungan ini adalah cabe, kubis, kentang, semangka, tomat, petai/ sawi, kacang panjang dan buncis. Oleh sebab itu produksi jumlah sayuran Provinsi Sumatera Utara pada tahun 2025 akan memenuhi kebutuhan sayuran untuk ketahanan pangan asalkan kebutuhan lahannya disediakan. Tabel 27 menyajikan perbandingan proyeksi produksi padi, jagung dan sayuran pada tahun 2025 dengan produksi padi, jagung dan sayuran untuk memenuhi kebutuhan ketahanan pangan.

Tabel 27. Perbandingan Proyeksi Produksi Padi, Jagung dan Sayuran Pada Tahun 2025 dengan Produksi Padi, Jagung dan Sayuran Untuk Memenuhi Kebutuhan Ketahanan Pangan

\begin{tabular}{lccc}
\hline & $\begin{array}{c}\text { Kebutuhan Untuk } \\
\text { Ketahanan Pangan } \\
\text { Tahun 2025 }(\mathbf{k g})\end{array}$ & $\begin{array}{c}\text { Proyeksi Produksi } \\
\text { Tahun 2025 }(\mathbf{k g})\end{array}$ & $\begin{array}{c}\text { Kelebihan/Kekurangan } \\
(\mathbf{k g})\end{array}$ \\
\hline Padi (beras) & 1.782 .733 .576 & 3.879 .772 .000 & 2.097 .038 .424 \\
Jagung & $56.567 .507,7$ & 2.228 .172 .000 & 2.171 .604 .492 \\
Sayuran & 1.007 .930 .137 & 1.602 .711 .000 & 594.780 .863 \\
\hline
\end{tabular}

Hasil perbandingan analisis kesesuaian lahan untuk tanaman tahunan dengan proyeksi kebutuhan luas tanah untuk perkebunan sampai tahun 2025 menunjukkan bahwa dari hasil proyeksi, ditemukan bahwa kebutuhan lahan untuk menampung perkembangan 
perkebunan mencapai 2.483.449,80 ha. Berdasarkan kesesuaian lahan, lahan untuk tepat untuk tanaman tahunan adalah sebesar 2.148.941,88 ha. Oleh sebab itu dapat dilihat bahwa berdasarkan kesesuaian lahan, pada tahun 2025 akan terjadi kekurangan lahan untuk perkebunan sebesar 334.507,92 ha. Tabel 28 menyajikan perbandingan proyeksi kebutuhan lahan untuk perkebunan dengan ketersediaan lahan untuk tanaman tahunan. Pada kenyataannya, ditemukan bahwa pada lahan yang tepat dijadikan kawasan tanaman tahunan sebesar 2.148.941,88 ha tersebut, ada yang masih berupa hutan primer, hutan sekunder, dan ada yang sudah menjadi permukiman dan sawah sebesar 456.316, 53 ha. Hal ini harus menjadi perhatian penting, mengingat perkebunan merupakan salah satu sektor unggulan Provinsi Sumatera Utara.

\section{Tabel 28. Perbandingan Proyeksi Kebutuhan Lahan Untuk Perkebunan Dengan Ketersediaan Lahan} Untuk Tanaman Tahunan Berdasarkan Kesesuaian Lahan

\begin{tabular}{ccc}
\hline $\begin{array}{c}\text { Kebutuhan lahan untuk } \\
\text { perkebunan (ha) }\end{array}$ & $\begin{array}{c}\text { Lahan untuk tanaman } \\
\text { tahunan berdasarkan } \\
\text { Kesesuaian Lahan (ha) }\end{array}$ & Kekurangan/kelebihan (ha) \\
\hline $2.483 .449,80$ & $2.148 .941,88$ & $-334.507,92$ \\
\hline
\end{tabular}

\section{Kesimpulan}

Hasil proyeksi kebutuhan lahan pertanian di Provinsi Sumatera Utara menunjukkan bahwa kebutuhan lahan untuk komoditas padi dan palawija hingga tahun 2025 sebesar 1.587.088 ha. Namun jika dibandingkan dengan kesesuaian lahan untuk pertanian semusim lahan basah, akan terdapat kekurangan seluas 596.485,44 ha dikarenakan adanya konversi alokasi lahan pertanian menjadi area permukiman, perkebunan, dan kebun campuran serta masih berupa hutan primer dan sekunder. Berbeda dengan tanaman sayuran yang pada tahun 2025 membutuhkan lahan seluas 105.645,67 ha sedangkan ketersediaan lahan untuk tanaman semusim tanah kering dan tanah basah seluas 1.516.008,74 ha sehingga masih akan terdapat kelebihan lahan sebesar 1.410.363,07 ha. Kebutuhan lahan untuk kwasan perumahan juga terdapat kekurangan seluas $185.638,54$ ha dimana proyeksi kebutuhan lahan permukiman di tahun 2025 seluas 210.293,97 ha namun ketersediaan lahannya hanya sebesar 24.655,43 ha. Jika dikaitkan dengan ketahanan pangan di Provinsi Sumatera Utara, proyeksi produksi komoditas padi, jagung dan sayuran hingga tahun 2025 sudah memenuhi kebutuhan pangan penduduk.

Kekurangan lahan permukiman tidak hanya disebabkan jumlah penduduk yang terus bertambah, melainkan juga karena keterbatasan lahan yang ada (diukur melalui SKL), sehingga alternatif jalan keluarnya adalah pengembangan teknologi agar lahan yang tidak layak untuk permukiman bisa menjadi layak. Kekurangan lahan pertanian juga bisa diselesaikan dengan cara pengembangan teknologi dan intensifikasi pertanian.

\section{Daftar Pustaka}

Badan Ketahanan Pangan Sumatera Utara. (2011). Grand design badan ketahanan pangan Sumatera Utara 2011-2025. Medan: Badan Ketahanan Pangan Provinsi Sumatera Utara.

Badan Pusat Statistik Provinsi Sumatera Utara. (2012). Indikator pertanian Sumatera Utara tahun 2012. Medan: BPS Provinsi Sumatera Utara.

Badan Pusat Statistik Provinsi Sumatera Utara. (2012). Statistik tanaman holtikultura Sumatera Utara tahun 2012. Medan: BPS Provinsi Sumatera Utara. 
Badan Pusat Statistik Provinsi Sumatera Utara. (2012). Statistik tanaman padi dan palawija Sumatera Utara tahun 2012. Medan: BPS Provinsi Sumatera Utara.

Bappeda Provinsi Sumatera Utara. (2013). Rencana tata ruang wilayah Provinsi Sumatera Utara tahun 20132033. Medan: Bappeda Provinsi Sumatera Utara.

Dickson, K. (2012). Analisis regresi linier sederhana. Retrieved from http://teknikelektronika.com/analisisregresi-linear-sederhana-simple-linear-regression/.

Kementerian Pekerjaan Umum Republik Indonesia. (2007). Permen PU no 20/PRT/2007 tentang pedoman teknik analisis aspek fisik dan lingkungan, ekonomi, serta sosial budaya dalam penyusunan rencana tata ruang. Jakarta: Kementerian Pekerjaan Umum RI.

Lillesand, T. M., \& Kiefer, R. W. (1979). Penginderaan jauh dan interpretasi citra (Dulbahri, dkk, Trans.). Yogyakarta: Gadjah Mada University Press.

Moniaga, V.R.B. (2011). Analisis daya dukung lahan pertanian. ASE, 72), 61-68.

Nurhayati, M. (2009). Strategi optimasi daya dukung sumber daya air di Kota Bekasi. Retrieved from https://core.ac.uk/download/files/451/12126814.pdf.

Thamrin, H. (2012). Pesatnya pertumbuhan perumahan dan permukiman menimbulkan dampak bagi prasarana dan pengelompokan hunian. Jurnal Saintek, 26(1). Retrieved from Lembaga Penelitian Insitut Teknologi Medan, Medan. 